\title{
An Assessment of Economic Efficiency of Smallholder Irish Potato Producers in Nyanga District of Zimbabwe
}

\author{
Ruvaraishe Tapera*, Dube Phamela and Nyasha Chipunza \\ Department of Agricultural Economics and Development, Manicaland State University of Applied Sciences \\ Corresponding author*
}

\begin{abstract}
The purpose of this study was to analyse the technical and resource use efficiency of the smallholder potato farmers in Nyanga District. Measuring the efficiency levels at farm level will help inform whether farmers are using the production resources to full potential given that efficiency can be used as an indication of performance A purposive sampling method was employed in selecting 10 villages with Irish potato producers, 180 respondents were selected using the systematic random sampling method. The Stochastic Frontier Approach with the application of the Cobb Douglas function and inefficiency was used to analyse technical efficiency while allocative efficiency of the production inputs was measured using Marginal Productivity Analysis. The results show that the mean technical efficiency is estimated at $55.5 \%$ with a minimum of $4.6 \%$ and a maximum of $84.2 \%$. Seed, labour and fertilizers positively contributed towards the improvement in the level of efficiency. The analysis further revealed that age of the farmer negatively influenced technical efficiency and experience positively influenced efficiency. The results also show that the farmers are operating at increasing returns to scale with returns to scale coefficient of 1.131. Computed allocative efficiency indices of the inputs showed that seed $(0.305)$ was over utilized while fertilizer (1.207) and labour (5.833) were underutilized. The analysis shows that $79 \%$ of the variation in the Irish potato output is as a result of technical inefficiency. In order to enhance technical efficiency levels of the farmers the government and stakeholders in the potato sector should facilitate training and support programmes targeted for younger farmers to encourage them to engage in production of the crop. Improved farmer's education will help farmers to allocate their production resources more efficiently. Use of improved quality seed reduces the replanting and overutilization of seed in potato production. Adherence to recommended production practices can also ensure that fertilizers are used at economic rates.
\end{abstract}

Keywords: Irish Potato Production, Technical and Allocative efficiency, Stochastic Frontier Approach, returns to scale

\section{INTRODUCTION}

G iven high unemployment levels prevailing in Zimbabwe, the horticultural sector offers strategies toward creating forward and backward linkages in value chains. With adequate attention, the sector is capable of penetrating international market thus generating foreign currency, creating employment and benefiting the economy as a whole. There are several conditions which make horticultural production a favourable enterprise in Zimbabwe. These include suitability of the climatic conditions to the requirements of the crop, the profusion of land, the existence of a consistent demand-supply system (Mpande and Madziwa, 2011).

Nutritionally Irish potatoes are renowned for their high carbohydrates content and can be a good substitute for other starchy foods like rice, wheat and maize (Mpemba, 2017). Consumer diets are diversifying with a surge in demand for potatoes, thus making the cultivation of potatoes increasingly important to the farmers. In 2012 the government declared it a strategic national food security crop thus enforcing its importance to food security (Herald, 2012). However, the agricultural policies and resources focused on the production of cash crops have little attention to potato production (Sakadzo et al., 2020).

Prior to the land reform program potato production was commercially practised by white farmers (Svubure, 2017). The land reform program restructured commercial agriculture giving rise to two resettlement programs A1 and A2. The A1 denotes the communal area land allocation system while the A2 denotes small to medium scale farm sizes between 35 to 300 ha (Mkodzongi \& Lawrence, 2019). These newly resettled farmers married the remaining commercial farmers and a few communal producers in the production of potatoes. The emergent farmers, have different resource means with the majority of them being resource constrained thus translating into diverse management strategies and this has a bearing on resource use efficiency and yield, (Svubure et al., 2017). Potato production cost are projected between US\$4500 to US\$6500 which is a way too high for emergent small-scale farms (Herald 2020).

The recognition of Irish potato as a food security crop makes it eligible for farmer supportive initiatives like mechanization and irrigation capacity (Svubure et al., 2017). However, the sector has not received much attention through policy. This is despite the realization that the crop can be used as an alternative in the bid to meet the dietary requirements of an ever-increasing population (Sakadzo et al., 2020). The area under potato cultivation is about 3500 hectares annually with an expected average productivity of 20 tonnes per hectare (FAOSTAT, 2013; Sakadzo et al., 2020). Off late, the annual production of potatoes has stood at an average of 58000 tonnes with a general stagnation or decline over the past few 
years (Sakadzo et al., 2020). The unstable trend in production volumes has been attributed to lack of improved seed varieties structures, high starting up costs, unreliable rainfall, poor management as well as poor skills, lack of technology adoption and utilization among others.

Although the government banned the importation of seed potato in favour of local seed producers, research and development has not been effective to come up with high yielding varieties. As a result, the sector has suffered from low yielding varieties of 20 tonnes per hectare yet other countries now use high yielding varieties of 80tonnes per hectare (Maganga 2012, Herald 2020, Sakadzo 2020). Furthermore, the sector lacks credit facilities therefore farmers prefer to take up the funded crops like maize under Command Agriculture. The study by Svubure et al., (2015) on yield gap analysis for Irish potato production systems in Zimbabwe also conforms to other literature sources in that the potential yield for communal systems in the Eastern Highlands of Nyanga are far below the potential yield of $95,8 \mathrm{t} / \mathrm{ha}$ when the crop is grown under conditions of non-limiting water and nutrient supply. The average actual yield for communal systems in Nyanga was $17 \mathrm{t} / \mathrm{ha}$ which translated to a yield gap of above $70 \%$ compared to the potential yield (Svubure et al., 2015). The best way to mitigating this problem is through supporting the adoption of appropriate technologies and improving the efficiency of input use. However, there is currently no evidence on the efficiency of producers in this sector. The demand for potatoes has been rapidly increasing given that a number of households are using potatoes as a substitute for starches such as rice and maize however local supply of fresh potatoes is currently being outstripped by demand on the local market resulting in high volumes being imported from South Africa (Herald, 2021).

Therefore, it is imperative to quantify the level of efficiency of the producers in order to approximate the production losses that may be caused by inefficiencies that result from differences in farm management practices as well as socioeconomic characteristics. The new agrarian landscape and the national strategic food security status of the Irish potato presents a perfect scenario to investigate and come up with ways of increasing potato production in Zimbabwe under the smallholder production sector given that they are the major producers of the crop in Zimbabwe. Most of the studies carried out on the Irish potato in Zimbabwe, have focussed on the estimation of costs of production, the impacts of adoption of production of the Irish potato on smallholder livelihoods and the factors determining potato yield, none studied the efficiency of farmers in Iris potato production (Nyagaka, 2009). Efficiency is a potential source of productivity growth and is therefore an indicator of productivity of the farm unit. This study focuses on the measurement of efficiency which will then help in the determination of whether the farmers are making use of all inputs to full potential or not. Farm level efficiency is useful not only to individual farmers but more importantly to policy makers when deciding the magnitude of agricultural support and ways in which resources should be allocated. In order to come up with appropriate policies and strategies, information is needed to understand the current levels of input use and determinants of efficiency. Therefore, the aim of this study is to determine the economic efficiency of the smallholder Irish potato farmers through achieving the following objectives:

i. To establish technical efficiency levels of smallholder potato producers in Nyanga district.

ii. To identify the factors that affect technical efficiency in Irish potato production in Nyanga district.

iii. To determine the allocative efficiencies of the inputs used in Irish potato production and the returns to scale for Irish potato in Nyanga district.

\section{THE CONCEPT OF ECONOMIC EFFICIENCY}

Efficiency is a relative concept and is defined as the actual productivity of a production unit relative to the maximum potential productivity. Technical efficiency is the potential of a farmer to produce a maximum possible level of output from a given set of inputs using available technologies (Ellis, 1988). A technically efficient farmer produces to full potential (on production frontier) while a technically inefficient farmer produces below potential (inside the frontier) given the existing technologies. However, producers may fail to produce at the full potential because of farm specific factors or random factors such as extreme weather phenomena (Battese and Coelli, 1995). Efficiency measurement allows for identification of farm specific factors that deter production along the frontier and separation of production effects from managerial effects on efficiency (Ogundari and Ojo, 2006). While allocative efficiency measures the degree to which an enterprise uses production inputs optimally in the right combination in order to maximize profits (Inoni, 2007). Hence, the allocatively efficient level of production is where the farm operates at the least cost combination of inputs. So economic efficiency is the product of technical efficiency and allocative efficiency and a farm that is both technically and allocatively efficient is economically efficient.

\section{Measurement of Technical Efficiency}

There are two approaches to measuring frontier functions and these include the parametric and non-parametric approaches. The Data Envelopment Analysis (DEA) (non- parametric approach) focuses on linear programming to create a stepwise frontier to accommodate the observations of other firms while the Stochastic Frontier Model (parametric approach) is based on the econometric estimation of the production frontier whose functional form is specified in advance. Relative to the Stochastic Frontier Model the DEA is merited for simultaneously quantifying inputs and outputs using different measurements. The advantage of Stochastic Frontier Model is that it can decompose the error term into two components i.e., the random and the inefficiency factor. This is particularly 
essential for farm level data that contains measurement errors as hypothesized (Masaka, 2016).

\section{The Stochastic Frontier Model}

The stochastic frontier model was developed by Aigner et al., (1977) for the purpose of estimating the technical efficiency of firms in production. Initially the production frontier assumes a stochastic production function with a multiplicative disturbance term of the form:

$$
Y_{i}=f\left(X_{i}, \beta_{i}\right) e^{\varepsilon_{i}}
$$

$Y$ denotes output, $\mathrm{f}($.$) refers to the production technology, X$ is the vector of inputs and $\beta$ is the vector of parameters to be estimated. The error term of the model is made up of two components

$\varepsilon_{i}=v_{i}-\mu_{i}$ where is $\mu_{i} \geq 0_{i}$

$v_{i}$ is the symmetric error term that captures the deviations from the potential production as a result of permissible or non-permissible conditions which a producer has no control over.

The measurement error term is assumed to be independent, identical and normally distributed $\mathrm{N}(0,1)$

$\mu_{i} \square$ denotes the inefficiencies that arise as a result of a farmer's failing to control factors of technical and economic efficiency.

Battese and Coelli (1995), argued that the model can be estimated using maximum likelihood technique where the consistent estimators of $\beta, \sigma$ and $\lambda$ can be obtained. The technical efficiency of an individual farmer is the ratio of the realized production to the corresponding frontier production given the level of technology. Mathematically, is expressed as the

$T E=\frac{f\left(X_{i}, \beta_{i}\right) \exp \left\{\varepsilon_{i}\right\}}{f\left(X_{i}, \beta_{i}\right) \exp \left\{v_{i}\right\}}=\frac{f\left(X_{i}, \beta_{i}\right) \exp \left\{v_{i}-\mu_{i}\right\}}{f\left(X_{i}, \beta_{i}\right) \exp \left\{v_{i}\right\}}=\exp \left(-\mu_{i}\right)$

The inefficiency function can be expressed as:

$\mu_{i}=\delta_{0}+\sum_{j=1}^{n} \delta_{j} \mathrm{z}_{j}+\omega_{i}$

Where $\mu_{i}$ resembles inefficiency scores for $i$ th farmer; $Z_{i}$ is denotes a vector for explanatory variable which explain the farmers' inefficiency, $\delta_{i}=$ Vector of unknown parameters to be estimated, and $\omega_{i}=$ unobservable random variables, which are assumed to be independently distribute

The likelihood function can be expressed as:

$\sigma^{2}=\sigma_{\mu}^{2}+\sigma_{v}^{2}$

And

$$
\lambda=\frac{\sigma_{\mu}}{\sigma_{v}}
$$

Where, $\sigma^{2}$ is the total variance for the combined error term $\varepsilon_{i}$; $\sigma_{v}^{2}$ is the constant variance for the symmetric error term $\sigma_{\mu}^{2}$ $\nu_{\mathrm{i}}$; is variance for the non-negative error term $\mu_{\mathrm{i}}$, and; $\lambda$ is ratio of farm specific efficiency effects to the total output variance. The overall variance of the model $\left(\sigma^{2}\right.$ is the sum variation of production from the frontier which can be likened to technical inefficiency. Lambda $(\lambda)$ represents the share of inefficiency in the overall residual variance with values between 0 and 1 . If $\lambda=1$, technical inefficiency is the dominant source of error and there is no effect of random errors in the data. On the other hand, if $\lambda=0$, it shows that the dominant source of error could be attributed to random factors alone and thus, no inefficiency effect (Adamu and Bakari, 2015 and Masaka, 2016).

\section{Study Area}

\section{METHODOLOGY}

This study was carried out in Nyanga district in Manicaland Province which is to the North East of Zimbabwe close to the border with Mozambique. The area receives more than $1000 \mathrm{~mm}$ of rainfall per year. During the cool season temperatures can be as low as 5 degrees Celsius and the dry season is shorter as compared to other regions lasting for about 2 months. Horticultural production is relatively prominent with farmers engaging in the fruit and vegetable production. Potato production is also most concentrated in this area. The district has several plantations and estates that provide employment. Figure 1 shows a map of Nyanga district and the wardsin the district.

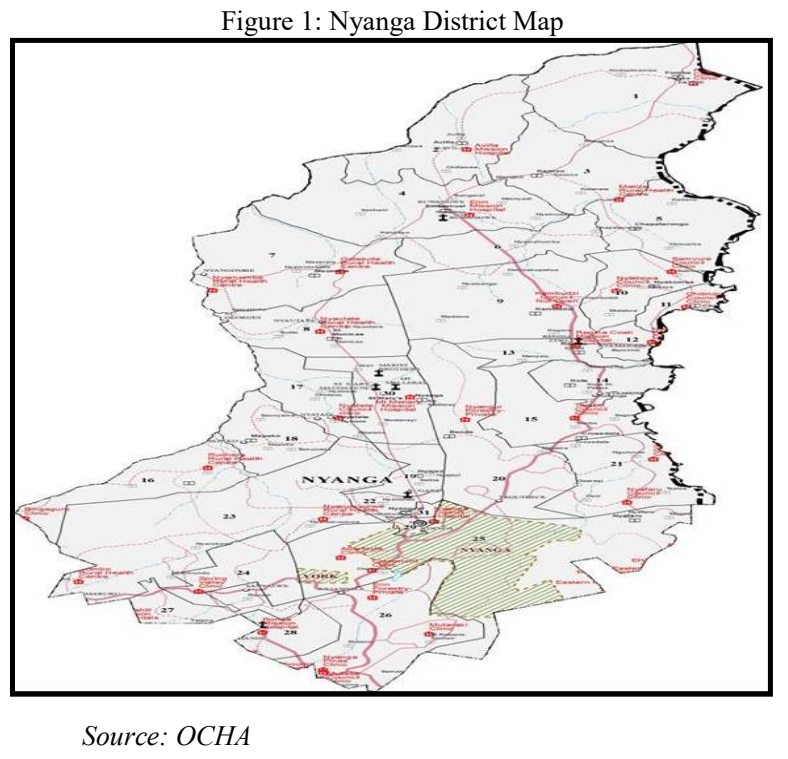

\section{Data Collection}

Purposive sampling was used in the selection of the 10 villages where data collection was carried out. Systematic random sampling was then used in the selection of 180 smallholder potato producers using a sampling frame obtained from the AGRITEX Nyanga District Office. For the chosen households, the farmer had to be on the list of potato producers that is maintained by Agricultural Extension. From the given list the first respondents of each village were 
selected randomly thereafter respondents were chosen after every fourth individual. 18 households were chosen from each of the villages A structured questionnaire was used in carrying out the survey and the information was collected regarding Irish potato production spanning from 2018-2020 seasons.

\section{Conceptual Framework}

Technical efficiency is a measure of how well an individual producer transforms inputs into a set of outputs. Two individuals using the same set of inputs and technology may produce different levels of output and part of the difference can be attributed to random variations found in aspects of life, differences in individual fundamental attributes and access to opportunities that could be influenced through public policies. In this study the dependent variable is the total output of Irish potatoes harvested by each individual farmer while the independent variables include total area planted with Irish potato, the amount of labor, which includes family and hired labor, the total quantity of chemical fertilizers used in Irish Potato farming and the total quantity of seed used. The conceptual framework for this study is shown in Figure 2 shown below.

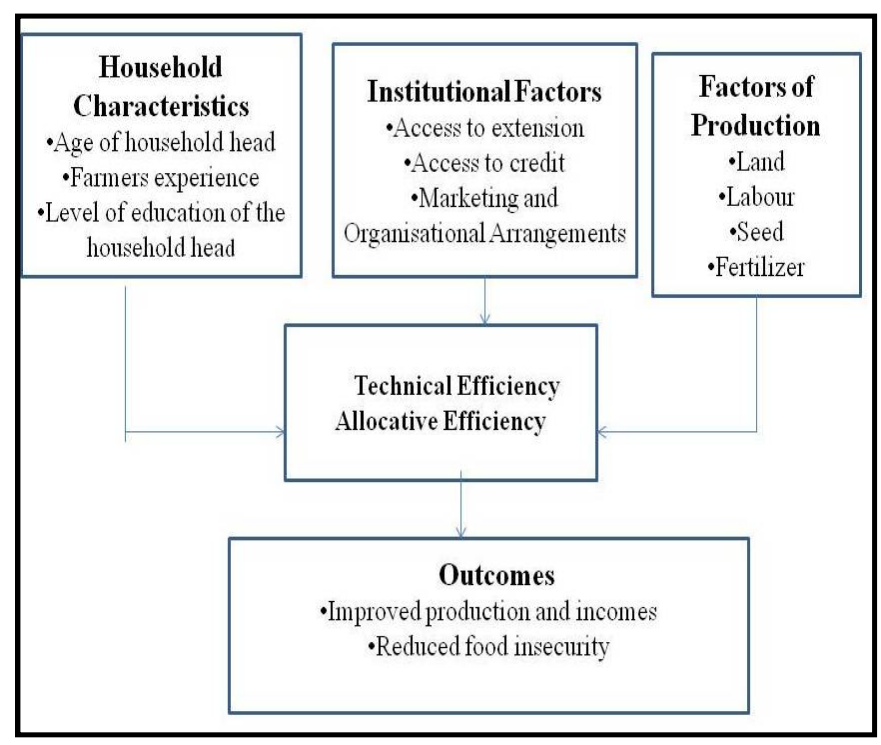

Figure 2: Conceptual Framework

\section{Model Specification}

The Cobb Douglas functional form is used in this study because its coefficients directly represent the elasticity of production and the level of multicollinearity between the variables is much less as compared to the translog functional form. Furthermore, the Cobb Douglas functional form has been widely used in farm efficiency analyses and has yielded plausible results. The Cobb Douglas model also has the advantage of allowing for simultaneous estimation of the farmers' level of efficiency as well as the determinants of technical efficiency (Battese and Coelli, 1995). The stochastic parametric method requires that a functional form of the frontier production function be specified and the chosen model for technical efficiency estimation is in the following form.

$\mathrm{Y}=\mathrm{f}($ Seed, Fertilizer, Land, Labor)

Where $\mathrm{Y}$ is the quantity of Irish potatoes produced in kilograms, Seed is the amount used for planting in kilograms, Land is the number of hectares used for growing potatoes in the particular season and labor is the number of labor hours employed by both family labor and hired labor in Irish potato production for the whole season. The total amount of fertilizer used includes both basal and top-dressing fertilizers used in the production of potatoes for the season. The stochastic production frontier is estimated by using the maximum likelihood procedure and the equation is given below:

$$
y_{i}=\ln \beta_{0}+\sum_{j=1}^{4} \beta_{j} \ln x_{j}+v_{i}-u_{i}
$$

which is then simplified to linear terms

$$
\ln y_{i}=\beta_{0}+\beta_{1} X_{1}+\beta_{2} X_{2}+\beta_{3} X_{3}+\beta_{4} X_{4}+e_{i}
$$

Where

$$
\begin{array}{llll}
\mathrm{Yi} & = & \text { yield of potatoes }(\mathrm{kg}) \\
\mathrm{X}_{1} & = & \text { size of farm land under potato production } \\
(\mathrm{ha}) & & \text { family and hired labor used for all activities } \\
\mathrm{X}_{2} & = & \text { fertilizers }(\mathrm{kg}) \\
(\text { labor hours) } & \text { seed in }(\mathrm{kg}) & \text { random variability in production that cannot } \\
\mathrm{X}_{3} & = & \text { influenced } & \text { farm specific error term } \\
\mathrm{X}_{4} & = & \text { parameters of linear terms also represent } \\
v_{\mathrm{i}} & = & \text { elasticities of production with respect to } \\
\text { be } & = & \text { each of the factors of production } \\
u_{\mathrm{i}} & = &
\end{array}
$$

Table 1: Variables included in the Cobb Douglas Model and the Hypothesized signs

\begin{tabular}{|c|c|c|}
\hline Variable & Description & $\begin{array}{c}\text { Hypothesized } \\
\text { sign }\end{array}$ \\
\hline Land & Land used for potato production (ha) & + \\
\hline Labour & $\begin{array}{c}\text { Labour used for all activities for Irish potato } \\
\text { production (labour hours) }\end{array}$ & + \\
\hline Fertilizer & $\begin{array}{c}\text { Amount of fertilizer used for potato production } \\
\text { (kgs) }\end{array}$ & + \\
\hline Seed & Amount of Irish potato seed planted (kgs) & + \\
\hline
\end{tabular}

It is expected that the parameters $\beta_{1}$ to $\beta_{4}$ (the linear parameters) are positive because an increase in any of the variables $X_{1}$ to $X_{4}$ will lead to increases in the technical efficiency of the farmers. The maximum likelihood estimates for the parameters of the stochastic frontier are obtained by using Stata Version 13. 


\section{ESTIMATION OF FACTORS AFFECTING TECHNICAL EFFICIENCY}

This study involves the determination of factors that affect the level of technical efficiency of the farmer's most importantly socio-economic variables of the sampled households. The Stochastic production frontier model and inefficiency model are run simultaneously using STATA version 13 . The farm specific inefficiency is suggested to be a function of socioeconomic variables and the inefficiency model is estimated as:

$$
I E_{i}=\delta_{0}+\sum_{j=1}^{6} \delta_{j} z_{j i}
$$

where $\delta_{0}$ is the intercept and $\delta_{\mathrm{j}}$ are the parameters estimated for the explanatory variables

$$
\begin{array}{lll}
Z_{1} & = & \text { Age of the household head } \\
Z_{2} & = & \text { Family size (Number of individuals in a }
\end{array}
$$$$
\text { household) }
$$$$
\mathrm{Z}_{3} \quad=\quad \text { Level of education attained by the }
$$
household head (years of schooling)

$$
\mathrm{Z}_{4}=\text { Access to credit }(1=\text { Yes, } 0=\text { Otherwise })
$$

$\mathrm{Z}_{5} \quad=\quad$ Farming experience (Number of years of practicing potato production

$\mathrm{Z}_{6}$

The linear form of the inefficiency model is:

\begin{tabular}{|c|c|c|}
\hline Variable & Explanation & $\begin{array}{l}\text { Expected } \\
\text { sign }\end{array}$ \\
\hline $\begin{array}{c}\text { Age of household } \\
\text { head }\end{array}$ & $\begin{array}{l}\text { Although farmers become more } \\
\text { skilfully as they grow older, the } \\
\text { learning by doing effect deteriorates } \\
\text { as farmers grow older as their physical } \\
\text { strength begins to decline. On the } \\
\text { other hand, older farmers are likely to } \\
\text { have more experience with farming } \\
\text { and may have accumulated more } \\
\text { capital through the years and therefore } \\
\text { are much preferred by credit service } \\
\text { providers. In such a case, older } \\
\text { farmers are expected to be more } \\
\text { efficient (Nyagaka, 2009). Therefore } \\
\text { the expected sign is either positive or } \\
\text { negative. }\end{array}$ & $+/-$ \\
\hline Family size & $\begin{array}{l}\text { The larger the household size the more } \\
\text { likely the household is efficient due to } \\
\text { more labour availability }\end{array}$ & - \\
\hline Level of education & $\begin{array}{l}\text { Education enhances the farmers ability } \\
\text { to derive decode and evaluate useful } \\
\text { information as well as improving } \\
\text { labour quality. Education also poses as } \\
\text { the human capital of the household } \\
\text { head. Therefore, the more the years of } \\
\text { schooling the higher the level of } \\
\text { technical efficiency. }\end{array}$ & - \\
\hline
\end{tabular}

$I E_{i}=\delta_{0}+\delta_{1} Z_{1}-\delta_{2} Z_{2}-\delta_{3} Z_{3}-\delta_{4} Z_{4}-\delta_{5} Z_{5}-\delta_{6} Z_{6}$

\begin{tabular}{|c|c|c|}
\hline $\begin{array}{c}\text { Access to credit, } \\
\text { Dummy } \\
(1=\text { YES }) \\
(0=\text { OTHERWISE })\end{array}$ & $\begin{array}{l}\text { Credit access is assumed to ease } \\
\text { liquidity problems hence farmers who } \\
\text { have access to credit are capable of } \\
\text { purchasing adequate production } \\
\text { inputs. The availability and use of } \\
\text { adequate capital shifts the production } \\
\text { frontier upwards resulting in higher } \\
\text { levels of technical efficiency } \\
\text { (Ohajianya et al., 2013). }\end{array}$ & - \\
\hline Farmer experience & $\begin{array}{l}\text { Experience contributes to better } \\
\text { decision-making including decisions } \\
\text { on input use and management. } \\
\text { Therefore, a farmer who has been } \\
\text { producing for a number of years is } \\
\text { likely to be more efficient as } \\
\text { experience is acquired through time. }\end{array}$ & - \\
\hline $\begin{array}{c}\text { Number of } \\
\text { extension visits }\end{array}$ & $\begin{array}{l}\text { Contact with Extension leads to more } \\
\text { efficient transmission of information } \\
\text { to farmers as well as enhancing the } \\
\text { adoption of innovations. Access to } \\
\text { extension is likely to influence a } \\
\text { farmer's decision to adopt a new } \\
\text { technology and his/her ability to use it } \\
\text { efficiently. }\end{array}$ & \\
\hline
\end{tabular}

Table 2: A priori expectations for the determinants of technical Efficiency

\section{Allocative Efficiency Estimation}

The Marginal Productivity Analysis is used in estimating the allocative efficiencies of the inputs used in production. The estimated coefficients for the parameters in the production model represent the elasticities of production with respect to each of the inputs and are used to obtain the value marginal products which are then compared with the respective marginal factor costs to obtain allocative efficiency indices for the resources used. This study assumes that Irish potato production is dependent on amount of seed used, fertilizers, land as well as labor. The allocative index for a farm producing output and using input $i$ is calculated as

$$
\mathrm{A} . \mathrm{E}=\frac{V M P_{i}}{P_{i}}
$$

Allocative efficiency is obtained by comparing the VMP of an input $\mathrm{i}$ and the Marginal Factor Cost $\mathrm{MFC}_{\mathrm{i}}$. However, farmers are price takers in the input market therefore the marginal cost of input $\mathrm{i}$ approximates the price of input $\mathrm{i}\left(\mathrm{P}_{\mathrm{i}}\right)$.

$$
V M P_{i}=P_{Y} * M P_{i}
$$

where

$$
\begin{array}{rlrl}
\mathrm{VMP}_{\mathrm{i}} & = & \text { Value Marginal Product of input } \mathrm{i} \\
\mathrm{P}_{\mathrm{Y}} & = & \text { Price of output } \mathrm{Y} \\
\mathrm{MP}_{\mathrm{i}} & =\quad \text { Marginal Physical Product of input } \mathrm{i} \\
\mathrm{P}_{\mathrm{i}} & =\quad \text { Price of input } \mathrm{i} \\
M P_{i} & =\frac{\partial Y}{\partial X}=\beta_{i} \frac{Y}{X_{i}}
\end{array}
$$


$\frac{Y}{X_{i}}=$ Average production and the $\beta$ s are the estimated coefficients from Ordinary Least Squares. $\mathrm{Y}_{\mathrm{i}}$ is the geometric mean of output and $\mathrm{X}_{\mathrm{i}}$ is the geometric mean of input $\mathrm{i}$.

If $\mathrm{AE}=1$ factor input is efficiently utilized

AE $<\quad 1$ factor input is overutilized and profits can be increased if the input in question is reduced. There is allocative inefficiency.

AE $>\quad 1$ factor input is underutilized, profits can be increased if input use is increased. There is allocative inefficiency.

AE $<0$ overutilization of input and gross inefficiency

\section{Returns to Scale}

The returns to scale coefficient or total output elasticity shows what would happen to output if all production inputs are varied by the same proportion in the long run (Kibaara, 2005). The returns to scale are calculated by summing up the partial elasticities of production with respect to all of the production inputs. The elasticities show the responsiveness of output to changes in inputs used in production.

- If the sum of the partial elasticities is equal to one, there are constant returns to scale.

- If the sum is greater than 1 , this indicates increasing returns to scale. This is stage I of the production function. A producer needs to expand production by allocating more of an input in order to reach stage II of production where production is optimal and efficient.

- If the sum is less than 0 , this shows decreasing returns to scale or negative returns to scale and this is stage III of production. Any increase in the allocation of input would result in a decrease in the output realized. At this stage, a producer needs to reduce his/her allocation of inputs in order to return to stage II of production.

- If the sum of the elasticities lies between 0 and 1 that is $0<\mathrm{RTS}<1$, there are positive decreasing returns to scale. In such a case, output production and allocation of inputs are optimal and efficient. An increase in input allocation would result in output increasing at a decreasing rate and this is stage II of a production function. Most producers aim to attain this stage of production (Esobhawan, 2010)

\section{ANALYTICAL FRAMEWORK OF THE STUDY}

The Analytical framework gives a summary of the objective, the data requirements and respective analytical tool that is applied for each objective. The analytical framework for this study is shown in table 3 .
Table .3: Analytical Framework

\begin{tabular}{|c|c|c|c|}
\hline Objective & $\begin{array}{l}\text { Research } \\
\text { Questions }\end{array}$ & Data Requirements & $\begin{array}{l}\text { Analytical } \\
\text { tool }\end{array}$ \\
\hline $\begin{array}{c}\text { To } \\
\text { Determine } \\
\text { technical } \\
\text { efficiency of } \\
\text { smallholder } \\
\text { potato } \\
\text { farmers }\end{array}$ & $\begin{array}{c}\text { Are } \\
\text { smallholder } \\
\text { Irish potato } \\
\text { producers } \\
\text { technically } \\
\text { efficient? }\end{array}$ & $\begin{array}{c}\text { Factors of } \\
\text { production, land, } \\
\text { labour, Seed, } \\
\text { Fertilizer, Output }\end{array}$ & $\begin{array}{c}\text { Stochastic } \\
\text { Production } \\
\text { Frontier } \\
\text { Approach } \\
\text { using Stata } \\
\text { Version } 13\end{array}$ \\
\hline $\begin{array}{l}\text { To } \\
\text { Determine } \\
\text { factors } \\
\text { affecting } \\
\text { technical } \\
\text { efficiency of } \\
\text { smallholder } \\
\text { potato } \\
\text { farmers }\end{array}$ & $\begin{array}{l}\text { What are the } \\
\text { factors that } \\
\text { affect } \\
\text { technical } \\
\text { efficiency } \\
\text { among potato } \\
\text { farmers in } \\
\text { Nyanga? }\end{array}$ & $\begin{array}{c}\text { Data on socio- } \\
\text { economic factors } \\
\text { i.e. age, household } \\
\text { size, years of } \\
\text { education, farming } \\
\text { experience, access } \\
\text { to credit, access to } \\
\text { extension, Input } \\
\text { costs i.e. costs of } \\
\text { fertilizer, labour, } \\
\text { seed }\end{array}$ & $\begin{array}{c}\text { Stochastic } \\
\text { Frontier } \\
\text { Approach } \\
\text { using Stata } \\
\text { Version } 13\end{array}$ \\
\hline $\begin{array}{l}\text { To } \\
\text { Determine } \\
\text { the Returns } \\
\text { to scale and } \\
\text { Allocative } \\
\text { efficiency } \\
\text { scores for } \\
\text { the inputs }\end{array}$ & $\begin{array}{l}\text { Do the Irish } \\
\text { potato farmers } \\
\text { allocate their } \\
\text { production } \\
\text { resources } \\
\text { efficiently and } \\
\text { realize } \\
\text { constants } \\
\text { returns to } \\
\text { scale? }\end{array}$ & $\begin{array}{c}\text { Factors of } \\
\text { production, costs of } \\
\text { inputs, output }\end{array}$ & $\begin{array}{c}\text { Maximum } \\
\text { Likelihood } \\
\text { Estimates } \\
\text { of the } \\
\text { Stochastic } \\
\text { production } \\
\text { frontier and } \\
\text { Marginal } \\
\text { Productivity } \\
\text { Analysis }\end{array}$ \\
\hline
\end{tabular}

\section{RESULTS AND DISCUSSION OF THE CHARACTERISTICS OF HOUSEHOLDS IN NYANGA DISTRICT}

\section{Descriptive Statistics}

The table 4, illustrates the demographic characteristics of Irish potato farmers sampled for this study.

Table 4: Demographic Characteristics of the Households

\begin{tabular}{|c|c|c|c|}
\hline Variable & Class & Frequency & Percent \\
\hline \multirow{2}{*}{ Gender } & Female & 32 & 17.9 \\
& Male & 148 & 82.1 \\
\hline \multirow{3}{*}{ Marital Status } & Single & 12 & 6.6 \\
& Married & 147 & 81.5 \\
& Widowed & 21 & 11.9. \\
\hline \multirow{3}{*}{ Access to } & Yes & 67 & 37.6 \\
credit & No & 113 & 62.4 \\
\hline & $25-35$ & 28 & 15.6 \\
Age (years) & $36-45$ & 61 & 34.1 \\
& $46-55$ & 44 & 24.3 \\
& $55+$ & 47 & 26.0 \\
\hline Years of & $1-7$ & 51 & 28.3 \\
formal & $8-14$ & 121 & 67.1 \\
education & $15+$ & 8 & 4.6 \\
\hline Total & & 180 & 100.0 \\
\hline
\end{tabular}

Source: Survey Data

\section{Years of formal education obtained by household head}

From the Table 4 it is noted that $67.1 \%$ of the farmers obtained between $8-14$ years of education indicating that most 
of the farmers reached secondary school. Therefore, the majority of the household heads were likely to encounter less difficulties in processing and applying information they would have acquired through extension and other sources which require some considerable level of literacy to understand the information given. Education also helps farmers in making better informed decisions for their farming enterprises.

\section{Age of the household}

The majority of the household heads were in the 36-45 age group implying that the majority of the household heads were middle aged and active with the capability of producing efficiently. Younger farmers tend to be more willing to adopt new methods that contribute to increased production as compared to older famers who are less willing to adopt new techniques and adhere to their traditional practices. As a result, younger farmers are more likely to increase their productivity. On the other hand, increase in age may also relate to more years in farming and therefore more experience.

\section{Access to credit}

$62.4 \%$ of the farmers did not have access to credit assistance and this could be attributed to the stringent measures that are normally set by the credit providers that make it difficult for farmers to meet the requirements for loan application. Some credit facility providers are also hesitant to provide such support as in the past, farmers have failed to honor their contracts and default in their repayment of the borrowed funds.

\section{Marital Status}

$81.5 \%$ of the sample household heads were married and this is likely to contribute to their decision making. Labor requirements for those who are married are met with less difficulty as compared to those who are single. A household whereby the head is married also translates to a bigger family size as compared to a household with a single household head. This in turn means that there is additional family labor to assist with farming activities.

\section{Gender}

Males constituted $82.1 \%$ of the sampled household heads, while females constituted $17.9 \%$. Most African societies are patriarchal in nature and man tend to be the sole owners of economic resources. All authority is vested upon them and they have ultimate control on the cultivation of cash crops.

\section{Irrigation Use}

The results on irrigation usage indicated that $96.5 \%$ of potato growers irrigated their crops. Irish potato is shallow rooted crop and very sensitive to water stress therefore cannot do well under dryland farming. Potatoes are also mostly grown on soils with medium to low water holding capacities hence it is very essential that an effective irrigation system be available so as to ensure maximum yields (King and Stark, 2009)

\section{Descriptive on Production Function}

Table 5: Summary Statistics of Variables in the Production Function

\begin{tabular}{|c|c|c|c|c|}
\hline & $\begin{array}{c}\text { Minim } \\
\text { um }\end{array}$ & Maximum & Mean & $\begin{array}{c}\text { Standard. } \\
\text { dev }\end{array}$ \\
\hline $\begin{array}{c}\text { Output produced in } \\
(\mathrm{kg})\end{array}$ & 75 & 40300 & 6524.00 & 7122.74 \\
\hline $\begin{array}{c}\text { Quantity of fertiliser used } \\
(\mathrm{kg})\end{array}$ & 0 & 5000 & 667.23 & 707.52 \\
\hline Quantity of seed used (kg) & 60 & 6000 & 693.16 & 764.35 \\
\hline Labour hours & 8 & 888 & 180.91 & 152.12 \\
\hline
\end{tabular}

Source: Survey data

On average the farmers managed to produce $6524 \mathrm{~kg}$ of potatoes as shown in Table 5 . The locally attainable yield in the country is about 20 tonnes/ha. Low levels of output could be attributed to limited use of fertilizers which are somehow critical in Irish potato production. A study done by Inoni (2007) suggested that output from agriculture can be undermined by small landholdings, lack of adequate inputs and use of traditional farming equipment.

The average amount of fertilizer used by the farmers was $667.23 \mathrm{~kg}$ with a minimum of zero kilograms. Some farmers were unable to acquire fertilizers due to credit constraints. The high costs of fertilizers substantially reduced the use of quality seeds, fertilizers and other vital inputs in crop production (Herald 2020). On average, the farmers used $693.16 \mathrm{~kg}$ of seed for production. The quantity and type of seed used by potato producers has some implications on the yield that is realized.

\section{Estimation of Technical Efficiency}

The Cobb Douglas functional model was estimated using Maximum Likelihood estimates and the model was run using Stata Version 13. The results of the estimation are shown in Table 6 below.

Table 6: Maximum Likelihood estimates of the Cobb Douglas Production Function

\begin{tabular}{|c|c|c|c|c|c|}
\hline & $\begin{array}{c}\text { Paramete } \\
\mathrm{r}\end{array}$ & Coefficient & $\mathrm{SE}$ & $\mathrm{z}$ & $\mathrm{P}>\mathrm{z}$ \\
\hline Lnseed & $\beta_{1}$ & 0.096 & 0.122 & 0.790 & 0.431 \\
\hline Lnfertquanty & $\beta_{2}$ & 0.257 & 0.123 & 2.080 & $0.037^{* *}$ \\
\hline Lnlandarea & $\beta_{3}$ & 0.260 & 0.036 & 7.170 & $\begin{array}{c}0.000^{* *} \\
*\end{array}$ \\
\hline Lnlbrhrs & $\beta_{4}$ & 0.518 & 0.094 & 5.530 & $\begin{array}{c}0.000^{* *} \\
*\end{array}$ \\
\hline Cons & & 4.638 & 0.579 & 8.010 & 0.000 \\
\hline$\sigma_{\mathrm{v}}$ & & 0.490 & 0.742 & & \\
\hline$\sigma_{\mathrm{u}}$ & & 0.958 & 0.134 & & \\
\hline$\sigma^{2}$ & & 1.158 & 0.211 & & \\
\hline$\Lambda$ & & 1.953 & 0.194 & & \\
\hline$\lambda=\left(\sigma_{\mathrm{u}}^{2} / \sigma_{\mathrm{u}}^{2}+\sigma_{\mathrm{v}}^{2}\right)$ & & 0.792 & & & \\
\hline $\begin{array}{c}\mathrm{Log} \\
\text { likelihood=- } \\
189.13294\end{array}$ & & & & & \\
\hline
\end{tabular}

Source: Survey data. ***,**, * mean significance at the $1 \%, 5 \%$ and $10 \%$ respectively 
From Table 6 lambda parameter which is the ratio of the unexplained error term to the total sum of errors is used to test for the presence of inefficiency in the model. The lambda parameter lies between 0 and 1 . If $\lambda$ was equal to zero, then inefficiency was absent from the model and in such instances the estimation would have been done using Ordinary Least Squares. In this study, the lambda parameter was used to test whether there were inefficiencies present in the model.

$$
\begin{aligned}
& \mathrm{H}_{0}: \lambda=0 \\
& \mathrm{H}_{1}: \lambda \neq 0
\end{aligned}
$$

As shown in the table 6 the value for lambda was equal to 0.79 therefore from this result, the null hypothesis that there is no technical inefficiency is rejected and we can conclude that inefficiency effects are significant in determining the variability of output of the Irish potato producers. We therefore conclude that the variations were as result of producer's management and socioeconomic characteristic rather than vagaries of nature. The ordinary least squares estimates (OLS) would not be adequate in explaining the inefficiencies on Irish potato production and this justifies the specification of a stochastic frontier production for this study. The Maximum Likelihood estimates of the Stochastic Production Function are shown in the equation below:

\section{$\ln Y i=4.638+0.257$ lnFetquanty +0.260 lnlandarea +0.518 lnlbrs}

All of the coefficients were positive as predicted in the apriori expectations thus increases in the respective inputs would result in increases in output. The estimated coefficients of the parameters $\left(\beta_{\mathrm{i}}\right)$ are the elasticities of production and give an indication of the responsiveness of output to changes in variable input holding other inputs constant. The partial elasticity for labor was $0.518 \quad(\mathrm{p}<0.01)$ meaning that an increase in labor by $1 \%$ would increase output by $0.518 \%$. Hence large families with active labor force or hired could afford to increase output if labor is effectively employed. Muthoni et al, (2009) and Jwanya et al, (2014), in that labor favors the expansion of potato production or increase in productivity because the enterprise is labor intensive, and combination of labor and appropriate application of fertilizers and chemicals gives splendid results.

The partial elasticity for the variable land was $0.260(p<0.01)$. This gives an indication that increasing land for Irish potato production would increase output. However, the effect of land on output involves other components such as soil fertility therefore if farmers are able to produce intensively using appropriate techniques on their land they can be assured of improved output. Similarly land had a positive influence of technical efficiency in a study by Kamau et al. (2020) but fertilizer application had a negative effect to technical efficiency to production in a similar study.

The variable fertilizer was also significant with a partial elasticity of $0.257(\mathrm{p}<0.05)$. This means that an increase in the amount of fertilizer by $10 \%$ for the Irish potatoes would result in an $2.57 \%$ increase in output

\section{Technical Efficiency Summary Statistics}

Table 7 shows the distribution of the technical efficiency scores of the sampled households. Table 71: Technical Efficiency

\begin{tabular}{|c|c|c|c|}
\hline \multicolumn{2}{|c|}{ Efficiency Scores } & Frequency & Percent \\
\hline \multicolumn{2}{|c|}{$0-0.19$} & 6 & 3.3 \\
\hline \multicolumn{2}{|c|}{$0.20-0.29$} & 11 & 6.1 \\
\hline \multicolumn{2}{|c|}{$0.30-0.39$} & 18 & 10.0 \\
\hline \multicolumn{2}{|c|}{$0.40-0.49$} & 23 & 12.8 \\
\hline \multicolumn{2}{|c|}{$0.50-0.59$} & 40 & 22.2 \\
\hline \multicolumn{2}{|c|}{$0.60-0.69$} & 34 & 18.9 \\
\hline \multicolumn{2}{|c|}{$0.70-0.79$} & 40 & 22.2 \\
\hline \multicolumn{2}{|c|}{$0.80-0.89$} & 8 & 4.4 \\
\hline Mean & $\begin{array}{c}\text { Standard } \\
\text { Dev }\end{array}$ & Max & Min \\
\hline
\end{tabular}
Scores

The predicted technical efficiencies shown in Table 7 range from a minimum of $4.4 \%$ to a maximum of $84.2 \%$. The mean technical efficiency score among the smallholder potato farmers was $55.5 \%$. This indicates that there is a wide disparity among the producers in terms of their level of technical efficiency. The mean technical efficiency shows that the level of output could be increased on average by $44.5 \%$ if producers were to produce on the most efficient frontier using the same level of inputs and following the best production practices. The technical efficiency scores show that none of the farmers were technically efficient as all of the scores for the farmers were less than one. This leads to the rejection of the null hypothesis that the smallholder potato producers in Nyanga District are technically efficient. The study conforms to the study by Aheisibwe et al., (2018) that the potato seed farmers were inefficient in their production.

\section{Estimation of factors affecting Technical Efficiency}

Table 8 shows the results of the inefficiency model comprising mainly of socio-economic factors that influence production.

Table 8: Inefficiency Model Estimates

\begin{tabular}{|c|c|c|c|c|c|}
\hline & Parameter & Coefficient & $\mathrm{SE}$ & $\mathrm{z}$ & $\mathrm{p}>\mathrm{z}$ \\
\hline Age & $\delta_{1}$ & 0.023 & 0.014 & 1.670 & $0.096^{*}$ \\
\hline Households & $\delta_{2}$ & 0.075 & 0.074 & 1.010 & 0.314 \\
\hline $\begin{array}{c}\text { Farmer } \\
\text { education }\end{array}$ & $\delta_{3}$ & -0.029 & 0.056 & $\begin{array}{c}- \\
0.520\end{array}$ & 0.605 \\
\hline $\begin{array}{c}\text { Credit } \\
\text { Access }\end{array}$ & $\delta_{4}$ & -0.288 & 0.324 & $\begin{array}{c}- \\
0.890\end{array}$ & 0.374 \\
\hline Exp & $\delta_{5}$ & -0.044 & 0.026 & $\begin{array}{c}- \\
1.720\end{array}$ & $0.086^{*}$ \\
\hline $\begin{array}{c}\text { Number of } \\
\text { visits }\end{array}$ & $\delta_{6}$ & -0.019 & 0.018 & $\begin{array}{c}- \\
1.040\end{array}$ & 0.298 \\
\hline Cons & & -0.788 & 1.103 & $\begin{array}{c}- \\
0.710\end{array}$ & 0.475 \\
\hline
\end{tabular}

***, **, *, significance at $1 \%, 5 \%$ and $10 \%$ level respectively 
Table 8 shows that Age and Experience significantly influence the level of inefficiency of the farmers. Age with a coefficient, 0.023 was significant at the $10 \%$ level since $\mathrm{p}<0.1$. Experience was also significant at the $10 \%$ level since $\mathrm{p}<0.1$. A negative sign for the coefficient implies that any increase in the variable would result in a reduction in the level of technical inefficiency of the farmer. On the other hand, a positive sign indicates that any increase in the respective variable would result in an increase in the level of technical inefficiency of the farmer.

Age

The results indicated that the coefficient of the variable age was positive implying that an increase in the age of the farmer would result in an increase in the level of technical inefficiency and this could be attributed to the deterioration in physical strength as a farmer's age. The learning by doing effect also declines as age increases and there is high reluctance to adopt newly improved inputs since older farmers tend to be more traditional. The ability to supervise farming operations also decreases as farmers grow older. Younger farmers tend to be more skillful in terms of searching for information and using new techniques and this is likely to contribute to the improvement of their technical efficiency levels. These results contradict to Wassihum et al.,(2019) study which revealed that the age variable was negatively correlated to inefficiency the reason being that as the farmers grow older they become more skillful due to cumulative farming experiences. The study also ascertains that an increase in farming experiences contributes to an improved valuation of the essential and complexities of good farming decision-making and efficient use of input.

\section{Experience}

From table 8 it is depicted that the parameter for the variable experience is negative and significant. This interpretation to this is that experience is positively correlated to technical efficiency implying that an increase in experience lead to an increase in the level of technical efficiency in potato farming. This conforms to the study by Andaregie,\&Astatkie (2020), in that experience was one of the variables that influenced production of potatoes positively. Experienced farmers, would have acquired a lot of knowledge on potato production, through learning by doing and can make informed decisions Potato production is generally carried out under risky environmental conditions such as low rainfall patterns. In such cases, farmers who have been involved in the production of the crop for a longer period of time are able to make predictions on when to carry out some of the farming operations and the timing out of operations as compared to farmers who are less experienced

\section{Estimation of Allocative Efficiency of the producers}

The elasticities estimated using the Stochastic Production Function model was used to estimate Marginal Value Products for each of the inputs. Since almost all of the farmers owned the land they were using for cultivation, the variable land rent was dropped when the Marginal Value Products were calculated. Geometric means for output, fertilizer, seed and labor were calculated and are shown in the table of results. The average prices for seed, fertilizer and wage were $1.06,0.70$ and 1.03 respectively as calculated from the information given by the sampled farmers. Table 9 shows the calculation for $\mathrm{Z}$ (the Allocative efficiency index).

Table 9: Estimation of Allocative Efficiency

\begin{tabular}{|c|c|c|c|c|c|c|c|c|}
\hline $\begin{array}{c}\text { Variabl } \\
\mathrm{e}\end{array}$ & $\begin{array}{c}\text { Geome } \\
\text { an }\end{array}$ & APP & $\begin{array}{c}\text { Elastici } \\
\text { ty }\end{array}$ & MPP & $\mathrm{P}_{\mathrm{y}}$ & $\begin{array}{c}\mathrm{MV} \\
\mathrm{P}\end{array}$ & $\mathrm{P}_{\mathrm{i}}$ & $\mathrm{Z}$ \\
\hline $\mathrm{Y}$ & $\begin{array}{c}3493.9 \\
23\end{array}$ & & & & & & & \\
\hline Seed & $\begin{array}{c}446.36 \\
1\end{array}$ & 7.828 & 0.096 & 0.751 & $\begin{array}{c}0.4 \\
3\end{array}$ & $\begin{array}{c}0.32 \\
3\end{array}$ & $\begin{array}{c}1.0 \\
6\end{array}$ & $\begin{array}{c}0.30 \\
5\end{array}$ \\
\hline $\begin{array}{c}\text { Fertiliz } \\
\text { er }\end{array}$ & $\begin{array}{c}456.94 \\
6\end{array}$ & 7.646 & 0.257 & 1.965 & $\begin{array}{c}0.4 \\
3\end{array}$ & $\begin{array}{c}0.84 \\
5\end{array}$ & $\begin{array}{c}0.7 \\
0\end{array}$ & $\begin{array}{c}1.20 \\
7\end{array}$ \\
\hline Labour & $\begin{array}{c}129.53 \\
6\end{array}$ & $\begin{array}{c}26.97 \\
3\end{array}$ & 0.518 & $\begin{array}{c}13.97 \\
2\end{array}$ & $\begin{array}{c}0.4 \\
3\end{array}$ & $\begin{array}{c}6.00 \\
8\end{array}$ & $\begin{array}{c}1.0 \\
3\end{array}$ & $\begin{array}{c}5.83 \\
3\end{array}$ \\
\hline
\end{tabular}

$\mathrm{MPP}=\mathrm{APP} *$ elasticity $\quad \mathrm{MVP}=\mathrm{MPP} * \mathrm{P}_{\mathrm{y}}, \quad \mathrm{P}_{\mathrm{i}}=$ input price, $\quad \mathrm{P}_{\mathrm{y}}=$ output price $\mathrm{Z}=\mathrm{VMP} / \mathrm{P}_{\mathrm{i}}$

The results of the $Z$ index shown in Table 9 show that for Seed, $Z<1$, therefore seed is being underutilized. This can be attributed to lack of knowledge among the farmers. Such information on the appropriate quantities of inputs to use is usually acquired through training and extension services. With the current economic hardships, the main extension provider which is AGRITEX has limited capacity to reach all the farmers and to train them adequately on proper management and production techniques. Some of the sampled households did not receive any extension visits by the time of data collection period and this has a bearing on their performance. Seed potatoes were underutilized because farmers claimed that certified seed were expensive and costly to buy from reputable sources. Farmers scaled down use of seed potatoes and resorted to low plant population which also had an adverse effect to farmer productivity.

The index for fertilizer was 1.207 and this implies that the farmers were under utilizing the input. Underutilization of fertilizer may be failure of the farmers to acquire adequate fertilizer due to financial constraints. Earlier results showed that the minimum quantity of fertilizer used by the farmers was $0 \mathrm{~kg}$ implying that due to the exorbitant prices of fertilizers some farmers were unable to afford fertilizer.

The $\mathrm{Z}$ index for labor was 5.833 which implies that labor was being underutilized. This generally indicates that the households engage in other activities besides potato farming resulting in inadequate employment of labor in potato production. Contradictory results were obtained by Inoni (2007) in a study of the allocative efficiency in pond fish production in Nigeria. The allocative efficiency score for labour was less than one hence labour was being overutilised in the enterprise. The result that was obtained was mainly due to the fact that family labour is readily available and can be 
employed whenever a need arises resulting in it being overutilized.

\section{CONCLUSION}

The aim of this study was to estimate the technical efficiency of smallholder potato producers in Nyanga and the factors that influence the technical efficiency as well as the allocative efficiency of the inputs used in production. The results of the study show that the smallholder potato farmers were inefficient as their efficiency scores were all below 1 suggesting that there were some inefficiency present. However the coefficients of the maximum likelihood estimates for land, labour and fertilizer were positive and significant suggesting that if the respective inputs are used optimally, efficiency could be improved. The contribution of labour to the production of potatoes is more significant as labour had the highest elasticity. There was high variability in the technical efficiency scores of the farmers indicating that there is a wide disparity in the farmers' management ability and their resource means. The returns to scale show that the Irish potato producers were collectively producing in stage I of the production surface. The resource efficiency estimation revealed that the farmers were inefficient in terms of their allocation and utilization of production resources since there was no optimization achieved for any of the resources. The study revealed that more experienced farmers are likely to be more technically efficient as experience was statistically significant in determining the level of technical efficiency. Age of the household head was also a significant determinant of technical efficiency with technical efficiency declining as a farmer grows older.

The farmers put forward some constraints that they are facing in the production of Irish potatoes and these included high input costs, shortage of water, capital constraints and problems associated with proof of landownership. Without proof of tenure ownership some of the farmers could not acquire credit from loan providers as the institutions usually require proof of landownership as a form of collateral.

\section{RECOMMENDATIONS}

The wide variations in the current levels of technical efficiency of the farmers are an indication of the potential improvement that can be realized if farmers improve on their operations. Given that an increase in the age of a farmer would result in a decline in the level of technical efficiency resulting in low productivity and food insecurity, agricultural policy should target on attracting younger farmers who are in the productive age range to engage in Irish potato production. The ZIMASSET policy drafted in 2013 which has goals including youth indigenisation and empowerment could be used as a platform to encourage younger farmers to fully adopt this enterprise. Younger farmers who constitute the majority of the sampled farmers have the potential to achieve higher efficiency levels if more production resources and training programmes are targeted on them.
The study revealed that experience of the household head positively influences the level of technical efficiency of the farmer. Farmers in the study area can form small groups or cooperatives for the purpose of capacity building and sharing information on Irish potato production given that the level of experience among the farmers is varied. Inexperienced farmers can benefit from the experienced farmers and implement some of the ideas they gain.

The quality of seed that is used in crop systems is an important factor for increasing potato yields. Quality seeds have the ability to utilize fertilizers and water more efficiently (Hasanuzzaman, 2015).Therefore use of improved quality seed will reduce the replanting and overutilization of seed in potato production. Adherence to recommended production practices can also ensure that fertilizers are used economically.

Microfinance institutions and banks that provide credit facilities to farmers can contribute to improvement of efficiency through supporting farmers with loans. Improved access to credit can enable smallholder producers to acquire adequate inputs for production such as fertilizer and reduce underutilization which results in resource inefficiency. Agricultural loan input schemes such as the Zimbabwe Progressive Pensioner Trust (ZIMPPET) which is currently targeting pensioners who are into agriculture should also benefit farmers who are into horticultural production such as potato farmers.

The results of the study show that farmers are not using inputs in the right proportions, therefore there is need to increase the number of extension workers in the study area to train and educate farmers on the appropriate use of inputs.

\section{REFERENCES}

[1] Abedullah, Khuda, B. and Ahmad, B. (2006) 'Technical Efficiency and its Determinants in Potato Production, Evidence from Punjab, Pakistan', The Lahore Journal of Economics, 11(2), pp. $1-22$.

[2] Aheisibwe, A.R., Lokina, R.B. \& Hepelwa, A.S., (2018). Technical Efficiency in Seed Potato Production Systems in Uganda. Journal of Economics and Behavioral Studies, 10(3(J)), pp.122-140. Available http://dx.doi.org/10.22610/jebs.v10i3.2322.

[3] Andaregie, A., \& Astatkie, T. (2020). Determinants of technical efficiency of potato farmers and effects of constraints on potato production in Northern Ethiopia. Experimental Agriculture, 56(5), 699-709. doi:10.1017/S0014479720000253

[4] Aigner, D., Lovell, C. A. K. and Schmidt, P. (1977) 'Formulation And estimation Of Stochastic Frontier Production Function Models', Journal of Econometrics, 6(1), pp. 21-37. doi: 10.1016/0304-4076(77)90052-5.

[5] Battese, G. E. and Coelli, T. J. (1992) 'Frontier ProductionFunctions and technical efficiency - A Survey of empirical applications in agricultural-economics', Agricultural economics, 7, pp. 185-208. doi: 10.1016/0169-5150(92)90049-5.

[6] Battese, G. E. and Coelli, T. J. (1995) 'A Model for Technical Inefficiency Effects in a Stochastic Frontier Production Function for Panel Data', Empirical Economics, 20, pp. 325-332. doi: 10.1007/BF01205442.

[7] Ellis, F. (1988) Peasant economics: farm households and agrarian development. Cambridge: Cambridge University Press. 
[8] Esobhawan, A. (2010) Economic Efficiency of Aquaculture Production in Edo State, Nigeria, IIFET 2010 Montpellier Proceedings.

[9] Herald, 2020 Food security - Government embarks on potato seed production. Available at: https://www.herald.co.zw/just-in-foodsecurity-government-embarks-on-potato-seed-production/

[10] [10] Herald (2012) 'Potato deared strategic food security crop'. Available at: http://www.herald.co.zw/potato-declared-strategicfood-security-crop/

[11] [11] Inoni, O. E. (2007) 'Allocative efficiency in pond fish production in Delta State, Nigeria: a production function approach', Agricultura Tropica et Subtropica, 40(4), pp. 127-134. Available agriculturaits.czu.cz/pdf_files/vol_40_4_pdf/1Inonix.pdf

[12] Jwanya, B.A., Dawang, N.C., Mashat I.M., B.S Gojing (2014) Technical Efficiency of Rain-Fed Irish Potato Farmers in Plateau State, Nigeria: A Stochastic Frontier Approach. Developing Country Studies Vol.4, No.22. ISSN 2224-607X (Paper) ISSN 2225-0565 (Online). www.iiste.org

[12] Kamau, P.N., Gathungu, G.K. \& Mwirigi, R.N., (2020). Technical Efficiency of Irish Potato (Solanum tuberosum L.) Production in Molo Sub County, Kenya. Asian Journal of Advances in Agricultural Research, pp.1-9. Available at: http://dx.doi.org/10.9734/ajaar/2020/v13i330104.

[13] Kibaara, B. W.(2005) Technical Efficiency in Kenyan's Maize Production: An Application of the Stochastic Frontier Approach. Colorado State University.

[14] King, B. B. and Stark, J. C. (2009) Potato Irrigation Management.

[15] Maganga, A. M. (2012) 'Technical efficiency and its determinants in Irish potato production: Evidence from Dedza District, Central Malawi', African Journal of Agricultural Research, 7(12), pp. 192-197. doi: 10.5897/AJAR11.1463.

[16] Makhura, L. M. (2001) Overcoming transaction costs barriers to market participation of smallholder farmers in the Northern Province of South Africa. Pretoria.

[17] Mkodzongi, G., \& Lawrence, P. (2019). The fast-track land reform and agrarian change in Zimbabwe. Review of African Political Economy, 46, 159, 1-13. https://doi.org/10.1080/03056244.2019.1622210

[18] Mpande, R. and Madziwa, B. (2011) Policy and advocacy issues: Developing the organic agriculture sector in Zimbabwe: The case study of Mashonaland East Province. Available at: www.zoppa.org.zw/index.php/organic-

farming/downloads?download $=1$..

[19] Mpemba, T. R. (2016). Evaluation of new Irish Potato (Solanum tuberosum L.) Varieties for Yield Potential in Zimbabwe. Department of Agronomy Faculty of Natural resources Management and Agriculture Midlands State University, Zimbabwe

[20] Muthoni, K \& Nyamongo, D.O (2009). A Review of Constraints To Ware Irish Potatoes Production In Kenya.Journal Of Horticulture And Forestry 1(7);98-102. Retrieved 18 September 2013 from http://www.acedemicjournal.org/jhf

[21] Ogundari, K. and Ojo, S. O. (2006) 'An Examination of Technical, Economic and Allocative Efficiency of Small Farms: The Case Study of Cassava Farmers in Osun State of Nigeria', Bulgarian Journal of Agricultural Science, 7(3), pp. 185-195.

[22] Ohajianya, D. O., Onu, P. N., Ugwu, J. N., Osuji, M. N., Nwaiwu, I. U., Orebiyi, J, S., Godson-Ibeji, C, C. and Enyia, C, O. (2013) 'Technical Efficiency of Table Egg Producers in Imo State, Nigeria', Asian Journal of Agricultural Extension, Economics and Sociology, 2(2), pp. 118-127.

[23] Sakadzo, N., Mavugara, J and Musara, A. (2020), Critical Review of Value Chain for Irish Potato in Zimbabwe with Specific Regards to the Economic Policy: A Review\}, Agriculture Sciences, Vol 2., doi 10.30560/2n2p42.

[24] Svubure, O., Struik, P. C., Haverkort, A. J., \& Steyn, J. M. (2017). Analysis of the Potato (Solanum tuberosum) Value Chain in Zimbabwe. Outlook on Agriculture Journal, 46(1), 49-46. https://doi.org/10.1177/0030727017690655

[25] Svubure, O., Struik, P. C., Haverkort, A. J. and Steyn, J. M. (2015) 'Yield gap analysis and resource footprints of Irish potato production systems in Zimbabwe', Field Crops Research. Elsevier B.V., 178, pp. 77-90. doi: 10.1016/j.fcr.2015.04.002.

[26] Ugwumba, C. O. A. (2010) 'Allocative Efficiency of "Egusi" Melon (Colocynthis citrullus lanatus) Production Inputs in Owerri West Local Government Area of Imo State , Nigeria', 1(2), pp. 95-100.

[27] Wassihun, A.N., Koye, T.D. \& Koye, A.D. (2019) Analysis of technical efficiency of potato (Solanum tuberosum L.) production in Chilga District, Amhara National Regional State, Ethiopia. Economic Structures 8, (34). https://doi.org/10.1186/s40008-0190166-y 